OPEN ACCESS

Edited by:

Elaine Dennison

MRC Lifecourse Epidemiology Unit,

United Kingdom

Reviewed by:

Melissa Orlandin Premaor,

Federal University of Minas

Gerais, Brazil

Stefano Pagano,

University of Perugia, Italy

Deborah Merke

National Institutes of Health Clinical

Center (NIH), United States

Smita Jha,

National Institutes of Health (NIH)

Bethesda, United States, in

collaboration with reviewer DM

*Correspondence:

Swetha Rangaswamaiah

swetha.r83@gmail.com

Specialty section: This article was submitted to

Bone Research,

a section of the journal

Frontiers in Endocrinology

Received: 29 April 2020

Accepted: 22 June 2020

Published: 31 July 2020

Citation:

Rangaswamaiah $S$,

Gangathimmaiah V, Nordenstrom A and Falhammar H (2020) Bone Mineral

Density in Adults With Congenital

Adrenal Hyperplasia: A Systematic

Review and Meta-Analysis.

Front. Endocrinol. 11:493.

doi: 10.3389/fendo.2020.00493

\section{Bone Mineral Density in Adults With Congenital Adrenal Hyperplasia: A Systematic Review and Meta-Analysis}

\author{
Swetha Rangaswamaiah ${ }^{1,2 *}$, Vinay Gangathimmaiah ${ }^{3}$, Anna Nordenstrom ${ }^{4,5}$ and \\ Henrik Falhammar ${ }^{2,6,7,8}$
}

\begin{abstract}
1 Department of Diabetes and Endocrinology, The Townsville University Hospital, Townsville, QLD, Australia, ${ }^{2}$ Department of Endocrinology, Royal Darwin Hospital, Darwin, NT, Australia, ${ }^{3}$ Department of Emergency Medicine, The Townsville University Hospital, Townsville, QLD, Australia, ${ }^{4}$ Department of Women's and Children's Health, Karolinska Institutet, Stockholm, Sweden, ${ }^{5}$ Department of Pediatric Endocrinology, Astrid Lindgren Children's Hospital, Karolinska University Hospital, Stockholm, Sweden, ${ }^{6}$ Department of Endocrinology, Metabolism and Diabetes, Karolinska University Hospital, Stockholm, Sweden, ${ }^{7}$ Department of Molecular Medicine and Surgery, Karolinska Institutet, Stockholm, Sweden, ${ }^{8}$ Wellbeing and Chronic Preventable Diseases Division, Menzies School of Health Research, Darwin, NT, Australia
\end{abstract}

Background: Decreased bone mineral density (BMD) is a concern in patients with congenital adrenal hyperplasia $(\mathrm{CAH})$ due to lifelong glucocorticoid replacement. Studies till date have yielded conflicting results. We wanted to systematically evaluate the available evidence regarding BMD in adult patients with $\mathrm{CAH}$.

Methods: We searched Medline, Embase and Cochrane Central Register of Controlled Trials to identify eligible studies. Studies comparing BMD in CAH patients with age- and sex-matched controls were included. Age $<16$ years and absence of controls were exclusion criteria. Two authors independently reviewed abstracts, read full-text articles, extracted data, assessed risk of bias using Newcastle-Ottawa scale, and determined level of evidence using Grading of Recommendations Assessment, Development, and Evaluation methodology.

Results: Nine case-control studies with a total sample of 598 (cases $n=254$, controls $n=344$ ) met eligibility criteria. Median age was 31 years (IQR 23.9-37) and 65.7\% were female. Total body BMD (Mean Difference [MD]-0.06; 95\%Cl-0.07, -0.04), lumbar spine BMD (MD -0.05; 95\% Cl -0.07, -0.03) and femoral neck BMD (MD -0.07; 95\%Cl $-0.10,-0.05)$ was lower in cases compared to controls. Lumbar spine $T$-scores (MD $-0.86 ; 95 \% \mathrm{Cl}-1.16,-0.56)$ and $Z$-scores (MD $-0.66 ; 95 \% \mathrm{Cl}-0.99,-0.32)$ and femoral neck $T$-scores (MD $-0.7595 \% \mathrm{Cl}-0.95,-0.56$ ) and $Z$-scores (MD -0.27 $95 \% \mathrm{Cl}-0.58,0.04)$ were lower in cases.

Conclusion: $\mathrm{BMD}$ in adult patients with $\mathrm{CAH}$ was lower compared to controls. Although insufficient data precludes a dose-response relationship between glucocorticoid dose and BMD, it would be prudent to avoid overtreatment with glucocorticoids. 


\section{INTRODUCTION}

Congenital adrenal hyperplasia $(\mathrm{CAH})$ is a group of autosomal recessive disorders of adrenal steroid biosynthesis $(1,2)$. 21hydroxylase deficiency (21OHD) due to CYP21A2 mutation is the most common cause of $\mathrm{CAH}$ accounting for $95-99 \%$ of all cases (3-5), followed by 11 $\beta$-hydroxylase deficiency, $17 \alpha$-hydroxylase/17,20-lyase deficiency, $3 \beta$-hydroxysteroid dehydrogenase type 2 deficiency, P450 oxidoreductase deficiency, lipoid adrenal hyperplasia, and cholesterol side chain cleavage enzyme deficiency (4, 6-8). Clinically classic 21OHD is characterized by glucocorticoid deficiency and adrenal androgen excess with or without additional mineralocorticoid deficiency (2). Incidence of classic CAH varies between 1:14000 and 1:18000 live births of which $75 \%$ are salt-wasting (SW) type and rest are simple virilizing (SV) (2). Non-classic 21OHD is more common with a reported incidence between 1:200 and 1:1000 livebirths, but even more common in certain ethnicities $(9,10)$. The treatment goals are to prevent adrenal crisis and optimize growth, sexual maturation, and reproductive function which is accomplished by replacing glucocorticoid and mineralocorticoid in sufficient doses $(1,2)$. This will decrease the associated excessive adrenocorticotropic hormone (ACTH) secretion from the pituitary gland and prevents hyperandrogenism.

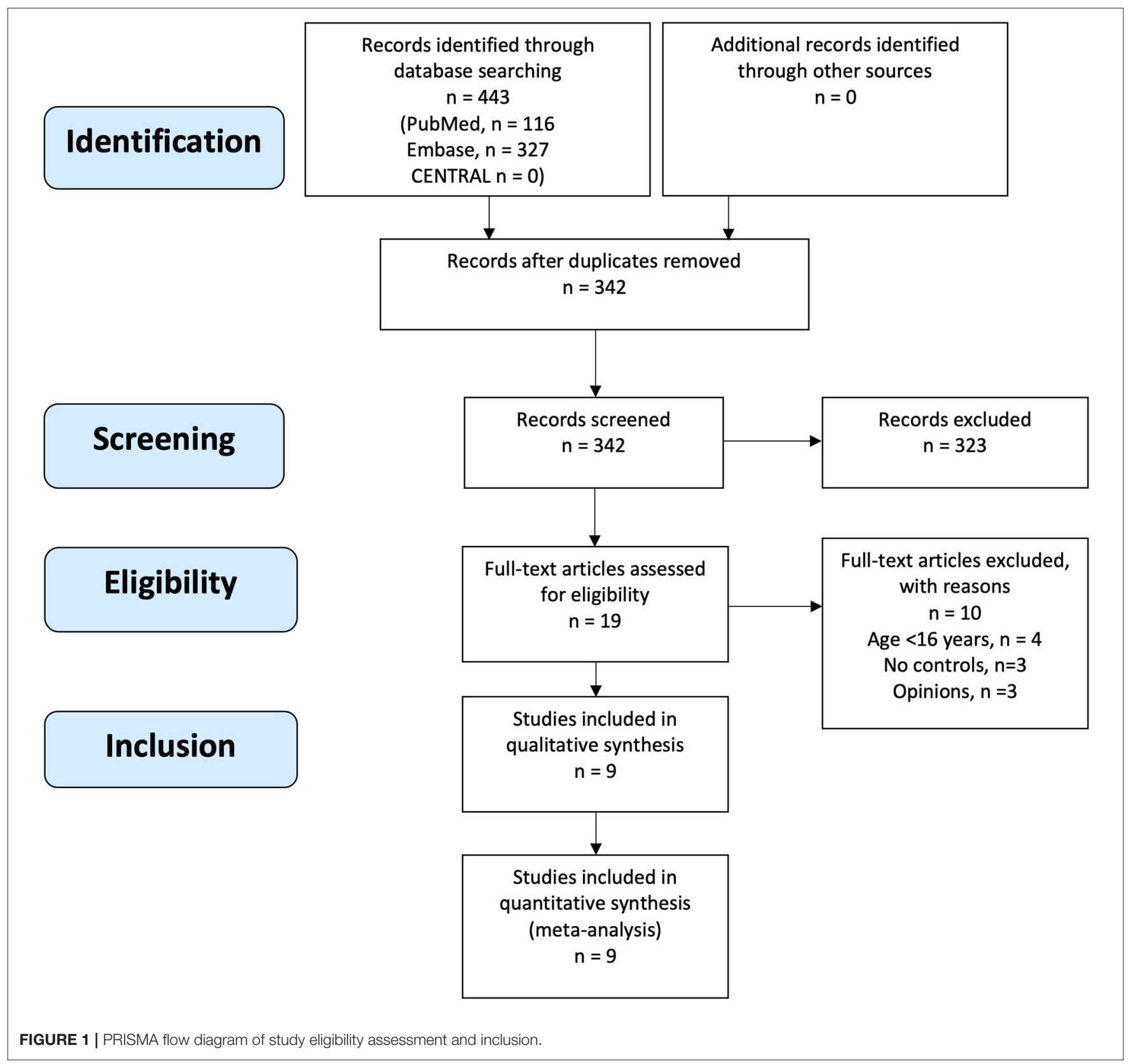


TABLE 1 | Characteristics of included studies of bone mineral density in adult patients with congenital adrenal hyperplasia and controls.

\begin{tabular}{|c|c|c|c|c|c|c|c|c|c|c|c|c|c|c|c|}
\hline $\begin{array}{l}\text { Study } \\
\text { first } \\
\text { author } \\
\text { and } \\
\text { year of } \\
\text { publication }\end{array}$ & $\begin{array}{l}\text { Study } \\
\text { location }\end{array}$ & $\begin{array}{l}\text { Total } \\
\text { sample } \\
\text { size }\end{array}$ & $\begin{array}{l}\text { Number } \\
\text { CAH }\end{array}$ & $\begin{array}{l}\text { Age } \\
\text { CAH }\end{array}$ & $\begin{array}{l}\text { Sex } \\
\text { CAH }\end{array}$ & $\begin{array}{l}\text { BMI } \\
\text { CAH }\end{array}$ & $\begin{array}{l}\text { Number } \\
\text { controls }\end{array}$ & $\begin{array}{l}\text { Age } \\
\text { controls }\end{array}$ & $\begin{array}{l}\text { Sex } \\
\text { controls }\end{array}$ & $\begin{array}{l}\text { BMI } \\
\text { controls }\end{array}$ & $\begin{array}{l}\text { Genetic } \\
\text { diagnosis; } \\
\text { CAH } \\
\text { variant }\end{array}$ & DXA & $\begin{array}{l}\text { BMD } \\
\left(\mathrm{g} / \mathrm{cm}^{2}\right) \\
\text { cases vs } \\
\text { controls }\end{array}$ & $\begin{array}{l}T \text {-score } \\
\text { cases } \\
\text { vs } \\
\text { controls }\end{array}$ & $\begin{array}{l}Z \text {-score } \\
\text { cases vs } \\
\text { controls }\end{array}$ \\
\hline $\begin{array}{l}\text { Ceccato } \\
2016(42)\end{array}$ & Italy & 76 & 38 & $\begin{array}{l}31 \pm \\
7 y\end{array}$ & $\begin{array}{l}24 \mathrm{M} \\
14 \mathrm{~F}\end{array}$ & $\begin{array}{l}25.6 \\
\pm 5.9\end{array}$ & 38 & $\begin{array}{l}31 \pm \\
7\end{array}$ & $\begin{array}{l}24 \mathrm{M} \\
14 \mathrm{~F}\end{array}$ & $\begin{array}{l}23 \pm \\
3.4\end{array}$ & $\begin{array}{l}\text { Y } \\
21 \mathrm{OHD} \\
\text { SW } n= \\
21 \\
\text { SV } n= \\
12 \\
\mathrm{NC} n \\
=5\end{array}$ & Hologic & $\begin{array}{l}\text { TB: }(-) \\
\text { LS: } \\
0.961+/-0.1 \\
\text { vs. } 1.02+/- \\
0.113 \text { FN: (-) }\end{array}$ & $\begin{array}{l}\text { TB: (-) } \\
\text { LS: (-) } \\
\text { FN: (-) }\end{array}$ & $\begin{array}{l}\text { TB: }(-) \\
\text { LS: } \\
-0.1+/- \\
1.0 \mathrm{vs} . \\
-0.3+/- \\
1.1 \mathrm{FN}:(-)\end{array}$ \\
\hline $\begin{array}{l}\text { Falhammar } \\
2007 \text { (36) }\end{array}$ & Sweden & 122 & 61 & $\begin{array}{l}24 \text { y } \\
(18- \\
29) \\
35 \\
\text { y (30- } \\
63)\end{array}$ & $\mathrm{F}$ & $\begin{array}{l}22.4 \\
(17.7- \\
41.8) \\
24.4 \\
(20.7- \\
48.3)\end{array}$ & 61 & $\begin{array}{l}24 \text { y } \\
(18- \\
29) \\
35 \\
\text { y (30- } \\
63)\end{array}$ & F & $\begin{array}{l}21.9 \\
(17.5- \\
33.8) \\
23.7 \\
(19.4- \\
39.9)\end{array}$ & $\begin{array}{l}\text { Y } \\
21 \mathrm{OHD} \\
\text { SW } n= \\
27 \\
\text { SV } n= \\
28 \\
\mathrm{NC} n \\
=6\end{array}$ & $\begin{array}{l}\text { Mainly } \\
\text { Lunar } \\
\text { (Hologic } \\
n= \\
3 \text { ) } \\
\end{array}$ & $\begin{array}{l}\text { TB: } \\
1.128+/- \\
0.016 \text { vs. } \\
1.186+/- \\
0.015 \text { LS: } \\
1.130+/- \\
0.025 \text { vs. } \\
1.237+/- \\
0.025 \text { FN: } \\
0.941+/- \\
0.025 \text { vs. } \\
1.039+/- \\
0.028\end{array}$ & $\begin{array}{l}\text { TB: } 0.03 \\
+/-0.20 \\
\text { vs. } \\
0.77+/- \\
0.19 \text { LS: } \\
-0.57+/- \\
0.20 \text { vs. } \\
0.32+/- \\
0.21 \mathrm{FN} \text { : } \\
-0.27+/- \\
0.19 \text { vs. } \\
0.45+/- \\
0.23\end{array}$ & $\begin{array}{l}\text { TB: } \\
0.0772 \\
+/-0.145 \\
\text { vs. } \\
0.933+/- \\
0.137 \text { LS: } \\
-0.736 \\
+/- \\
0.15 \text { vs. } \\
0.520+/- \\
0.232 \\
\text { FN: } \\
-0.567 \\
+/-0.165 \\
\text { vs. } 0.227 \\
+/-0.212\end{array}$ \\
\hline $\begin{array}{l}\text { Falhammar } \\
2013 \text { (37) }\end{array}$ & Sweden & 62 & 30 & $\begin{array}{l}35.7 \\
\pm \\
11.4 \\
y\end{array}$ & M & $\begin{array}{l}26.4 \\
\pm 4.7\end{array}$ & 32 & $\begin{array}{l}36.5 \\
\pm \\
11.9\end{array}$ & M & $\begin{array}{l}24.5 \pm \\
3.6\end{array}$ & $\begin{array}{l}\text { Y } \\
21 \mathrm{OHD} \\
\mathrm{SW} n= \\
17 \\
\mathrm{SV} n= \\
11 \\
\mathrm{NC} n \\
=2\end{array}$ & Lunar & $\begin{array}{l}\text { TB: } 1.17+/- \\
0.11 \text { vs. } \\
1.27+/-0.10 \\
\text { LS: } 1.16 \\
+/-0.20 \text { vs. } \\
1.23 \\
+/-0.16 \\
\text { FN: } 0.96 \\
+/-0.13 \\
\text { vs. } 1.05 \\
+/-0.14\end{array}$ & $\begin{array}{l}\text { TB: (-) } \\
\text { LS: (-) } \\
\text { FN: (-) }\end{array}$ & $\begin{array}{l}\text { TB: (-) } \\
\text { LS: (-) } \\
\text { FN: (-) }\end{array}$ \\
\hline $\begin{array}{l}\text { Guo } \\
1996 \text { (23) }\end{array}$ & $\begin{array}{l}\text { United } \\
\text { Kingdom }\end{array}$ & 22 & 11 & $\begin{array}{l}38.3 \\
\pm \\
14.3 \\
y\end{array}$ & $\begin{array}{l}6 \mathrm{~F} \\
5 \mathrm{M}\end{array}$ & $N R$ & 11 & $\begin{array}{l}38.3 \\
\pm \\
16.3 y\end{array}$ & $\begin{array}{l}6 \mathrm{~F} \\
5 \mathrm{M}\end{array}$ & NR & $\begin{array}{l}\mathrm{Y} \\
21 \mathrm{OHD} \\
\mathrm{SW}=3, \\
\mathrm{SV}= \\
\mathrm{NR}, \\
\mathrm{NC}= \\
\mathrm{NR} \\
11 \mathrm{OHD} \\
n=2\end{array}$ & Lunar & $\begin{array}{l}\text { TB: } 1.14+/- \\
0.11 \text { vs. } \\
1.176 \\
+/-0.19 \\
\text { LS: } 1.196 \\
+/-0.13 \text { vs. } \\
1.054+/-0.19 \\
\text { FN: } 0.95 \\
+/ 0.18 \text { vs. } \\
0.93+/-0.15\end{array}$ & $\begin{array}{l}\text { TB: (-) } \\
\text { LS: (-) } \\
\text { FN: (-) }\end{array}$ & $\begin{array}{l}\text { TB: (-) } \\
\text { LS: (-) } \\
\text { FN: (-) }\end{array}$ \\
\hline $\begin{array}{l}\text { Hagenfeldt } \\
2000 \text { (33) }\end{array}$ & Sweden & 26 & 13 & $\begin{array}{l}23.9 \\
\pm 0.8 \\
y\end{array}$ & $\mathrm{~F}$ & $\begin{array}{l}26.2 \\
\pm 1.7\end{array}$ & 13 & $\begin{array}{l}22.3 \\
\pm 0.4\end{array}$ & $\mathrm{~F}$ & $\begin{array}{l}20.7 \pm \\
0.3\end{array}$ & $\begin{array}{l}\text { Y } \\
21 O H D \\
\text { SW, } n= \\
12 \\
\text { SV, } n \\
=1\end{array}$ & Lunar & $\begin{array}{l}\text { TB: } \\
1.12+/-0.02 \\
\text { vs. } \\
1.13+/-0.02 \\
\text { LS: } \\
1.14+/-0.04 \\
\text { vs. } \\
1.13+/-0.03 \\
\text { FN: }(-)\end{array}$ & $\begin{array}{l}\text { TB: (-) } \\
\text { LS: (-) } \\
\text { FN: (-) }\end{array}$ & $\begin{array}{l}\text { TB: (-) } \\
\text { LS: (-) } \\
\text { FN: (-) }\end{array}$ \\
\hline
\end{tabular}


TABLE 1 | Continued

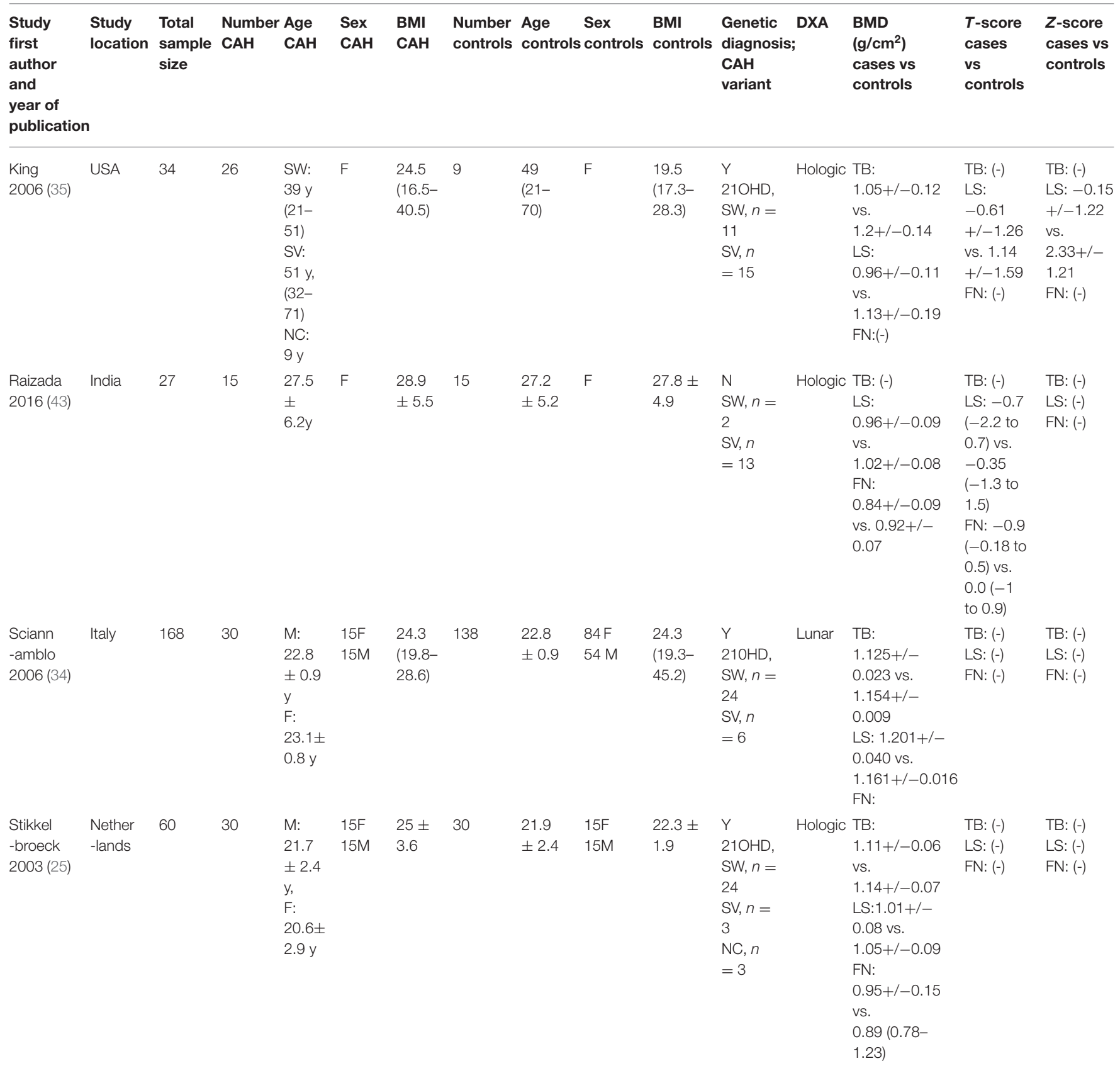

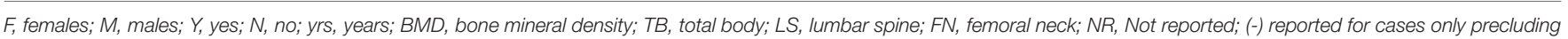
comparisons and conclusions; 21OHD, 21-hydroxylase deficiency; 11OHD, 11-hydroxylase deficiency; SW, salt wasting; SV, simple virilizing; NC, non-classic; NR, Not reported.

The balance between replacing deficient hormones and preventing hyperandrogenism can be difficult to achieve without overtreatment and its attendant risk of growth retardation and other clinical metabolic manifestations of glucocorticoid excess such as obesity, insulin resistance, diabetes, and hypertension $(3,4,11,12)$.

Decreased bone mineral density (BMD) and osteoporosis have been an important concern in patients with $\mathrm{CAH}$ due to lifelong glucocorticoid replacement. Glucocorticoids are a wellknown secondary cause of osteoporosis and increased fracture risk has been established by various epidemiological studies $(13,14)$. Glucocorticoids have direct and indirect effects on bone leading to initial increased resorption and later decease in bone formation which results in microarchitectural distortion and increased fracture risk (15-17). It has also been postulated that glucocorticoids can cause secondary hyperparathyroidism 
by reducing intestinal calcium absorption and raising renal calcium excretion.

Gonadal and adrenal androgens are stimulators of osteoblast proliferation and differentiation in both males and females (18). Dehydroepiandrosterone sulphate (DHEAS) and other adrenal androgens affect bone metabolism throughout life and particularly during adrenarche, with a main effect on cortical bone (19). Some studies suggest that children with classic $\mathrm{CAH}$ fail to have a physiological rise in DHEAS levels during childhood, effectively accounting for absence of a typical adrenarche (20). Low DHEAS as a result of blunted response in adrenals of $\mathrm{CAH}$ patients and due to the glucocorticoid effect can affect the growth and osteoblastic function in these patients and might be the cause of low BMD.

However, there have been conflicting results in the published literature regarding $\mathrm{BMD}$ in $\mathrm{CAH}$ patients. Some studies reported normal BMD (21-27) while other studies reported

TABLE 2 | Risk of bias assessment of included studies based on NOS and AHRQ.

\begin{tabular}{|c|c|c|c|c|c|}
\hline Study & Selection & Comparability & Exposure & Quality & Risk of bias \\
\hline $\begin{array}{l}\text { Ceccato } \\
2016(42)\end{array}$ & 4 & 2 & 1 & Poor & High \\
\hline $\begin{array}{l}\text { Falhammar } \\
2007 \text { (36) }\end{array}$ & 4 & 1 & 2 & Good & Low \\
\hline $\begin{array}{l}\text { Falhammar } \\
2013(37)\end{array}$ & 4 & 1 & 2 & Good & Low \\
\hline $\begin{array}{l}\text { Guo } \\
1996 \text { (23) }\end{array}$ & 2 & 2 & 2 & Fair & Moderate \\
\hline $\begin{array}{l}\text { Hagenfeldt } \\
2000 \text { (33) }\end{array}$ & 4 & 1 & 2 & Good & Low \\
\hline $\begin{array}{l}\text { King } \\
2006 \text { (35) }\end{array}$ & 4 & 2 & 2 & Good & Low \\
\hline $\begin{array}{l}\text { Raizada } \\
2016(43)\end{array}$ & 3 & 1 & 1 & Poor & High \\
\hline $\begin{array}{l}\text { Sciannamblo } \\
2006 \text { (34) }\end{array}$ & 4 & 1 & 1 & Poor & High \\
\hline $\begin{array}{l}\text { Stikkelbroeck } \\
2003(25)\end{array}$ & k & 1 & 1 & Good & Low \\
\hline
\end{tabular}

36. NOS-Newcastle Ottawa Scale. A study can be awarded a maximum of one star for each numbered item within the SELECTION and EXPOSURE categories while a maximum of two stars can be given for COMPARABILITY. The number items are as follows SELECTION 1. Is the case definition adequate? (a. yes with independent validation* b. yes record linkage based on self-reports c. no description) 2. Representativeness of Cases (a. consecutive or obviously representative series ${ }^{*} b$. potential for selection biases or not stated) 3. Selection of Controls (a. Community controls ${ }^{*}$ b. Hospital Controls c.no description) 4. Definition of controls (a. no history of disease* b. no description of source) COMPARABILITY 5. Comparability of cases and controls on the basis of design or analysis (a. study controls for ___(select the most important factor) ${ }^{*} b$. Study controls for any additional factor ${ }^{*}$ ) EXPOSURE 6. Ascertainment of Exposure (a. secure record like surgical records ${ }^{*}$ b. structured interview blinded to case/control status ${ }^{*}$ c. interview not blinded to case/control status $d$. written self-report or medical record only. e. no description) 7. Same method of ascertainment for cases and controls (a. yes ${ }^{*}$ b.no) 8. Non-response rate (a. same rate for both groups ${ }^{*} b$. non-respondents described c. rate different and no designation) ${ }^{37} \mathrm{AHRQ}$-Agency for healthcare research and quality standards. Good quality: 3 or 4 stars in selection domain AND 1 or 2 stars in comparability domain AND 2 or 3 stars in outcome/exposure domain; Fair quality 2 stars in selection domain AND 1 or 2 stars in comparability domain AND 2 or 3 stars in outcome/exposure domain; Poor quality 0 or 1 star in selection domain OR 0 star in comparability domain OR O OR 1 star in outcome/exposure domain. low BMD in all or some sites $(3,28-44)$ or even high BMD (45). Thus, the aim of this systematic review and meta-analysis was to review the available literature to assess if adult patients with $\mathrm{CAH}$ are at risk of decreased BMD compared to age- and sex-matched controls.

\section{METHODS}

\section{Eligibility Criteria}

Included studies had to have an exposure group consisting of patients aged 16 years or older with $\mathrm{CAH}$, a control group consisting of age- and sex-matched controls without $\mathrm{CAH}$, with standard BMD measures as outcomes of primary interest. Only clinical trials (RCTs and CCTs) and case-control studies were considered adapt to be included in this meta-analysis, eliminating any other study design such as studies with no ageand sex-matched controls, animal studies, reviews, editorials, news articles, case reports, case series, opinion pieces, and conference abstracts.

\section{Search Strategy}

PubMed/Medline, Embase and Cochrane Central Register of Controlled Trials (CENTRAL) were searched from inception to 31st July, 2019 using the following keywords: "Congenital Adrenal Hyperplasia," "CAH" "21-Hydroxylase," "11 $\beta$-hydroxylase," " $3 \beta$-hydroxysteroid dehydrogenase," " $17 \alpha$ hydroxylase," "Osteoporosis," "Osteopenia," "Bone mineral density," "Bone densitometry," "BMD" and "Bone metabolism." For details, please see Supplemental Table 1. No language restrictions were applied. The reference lists of included studies and non-included reviews were manually searched to identify additional studies.

\section{Study Screening and Data Extraction}

Four authors undertook the systematic review (SR, VG, AN, and $\mathrm{HF}$ ) with SR coordinating the review. Two authors (SR and VG) independently ran the searches, screened the titles and abstracts as well as reviewed full-text copies to identify eligible articles. SR and VG independently performed data extraction using a standardized data extraction form (Microsoft Excel, Microsoft Inc, 2016). Data was extracted regarding the following variables: first author, type of study, country, year of publication, number of cases and controls, age, gender, whether the diagnosis of CAH was genetically confirmed or not, phenotype of $\mathrm{CAH}$, body site, modality, and results of BMD measurements including $T$ - and $Z$-scores, type, and average daily dose of glucocorticoid used for treatment, levels of bone turnover markers, type, and number of fractures, body mass index, vitamin D, 17-hydroxyprogesterone, androstenedione, testosterone, dehydroepiandrosterone, and dehydroepiandrosterone sulphate (DHEAS). Bone turnover markers are the collagen breakdown products and other molecules that are produced by osteoclasts and osteoblasts during bone resorption and bone formation. Markers that are specific to bone formation include serum bone-specific alkaline phosphatase (BALP), osteocalcin, and N-terminal propeptide of type I procollagen (P1NP), whereas markers specific to bone resorption include urinary $\mathrm{N}$-terminal telopeptide of type I 
collagen (NTX), pyridinoline cross-links and serum C-terminal telopeptide of type I collagen (CTX).

An attempt was made to contact authors for clarification and additional data, if indicated. If such data could not be obtained, a decision was made to discuss its potential impact on the results. Disagreements were resolved by discussion and consensus. If consensus could not be reached, the last author (HF) made the final decision. The PRISMA (Preferred Reporting Items for Systematic Reviews and Meta-analyses) guidelines were followed (46).

\section{Data Synthesis}

RevMan 5.3 was used to conduct data analysis. Results were calculated as mean differences with $95 \%$ confidence intervals $(95 \% \mathrm{CI})$ for continuous data. $I^{2}$ statistic was used to assess statistical heterogeneity between studies and significant heterogeneity was assumed if $I^{2}$ was $>40 \%$. Meta-analyses using fixed-effect modeling were performed when the outcome data were found to be sufficiently clinically homogeneous. In the presence of significant heterogeneity, data was synthesized and presented qualitatively.

\section{Assessment of Risk of Bias of Individual Studies}

The risk of bias of individual studies was assessed independently by two authors (SR and VG) using a combination of the Newcastle-Ottawa Scale (NOS) (47), Agency for Healthcare Research and Quality (AHRQ) standards (48) and the reviewers' interpretation of study quality. NOS was chosen due to its validity, interrater reliability and ease of use in case-control studies. NOS allows assignment of scores under three domains and eight sub-domains while AHRQ standards allow conversion of NOS scores to a quality assessment of studies as good, fair or poor. We interpreted good quality studies to be at a low risk of bias, fair quality studies to be at moderate risk of bias and poorquality studies to be at high risk of bias. Publication bias was assessed graphically using funnel plots.

\section{Grading of the Body of Evidence}

The quality of evidence was assessed independently by two authors (SR ad VG) using Grading of Recommendation,
Assessment Development and Evaluation (GRADE) methodology (49) where evidence is graded on a quality continuum of high, moderate, low, and very low. GRADE methodology involves assigning a baseline quality of evidence based on study design which is usually low for observational studies and high for randomized trials with no significant limitations. Thereafter, there are five reasons for possible downgrading based on risk of bias, inconsistency, imprecision, indirectness, and publication bias. Reasons for possible upgrading include large magnitude of effect, dose-response gradient or if all plausible confounding would reduce the demonstrated effect or increase the effect if no effect was observed.

\section{RESULTS}

\section{Description of Studies}

The initial search yielded 443 records of which 342 records were screened after removal of duplicates. Nineteen articles underwent full text review, of which nine articles met eligibility criteria and were included (Figure 1). Manual search of reference lists of included articles and non-included reviews did not yield any additional eligible articles.

\section{Included Studies}

All nine included articles were case-control studies $(23,25,33-$ $37,42,43$ ) with a total sample size of 598 (cases $n=254$, controls $n=344$ ). Median age of participants was 31 years (interquartile range 23.9-37) and 65.7\% (393/598) were female. In all nine studies, cases were patients with $\mathrm{CAH}$ exposed to glucocorticoid use and controls were sex- and age-matched individuals without $\mathrm{CAH}$. Outcomes were one or more measures of BMD. The characteristics of included studies are presented in Table 1.

\section{Methodological Quality}

Three studies were found to be of poor quality $(34,42$, 43), one (23) of fair quality and the rest were found to be of good quality $(25,33,35-37)$ (Table 2). This was based on an initial score calculated using the NOS (47) which

\begin{tabular}{|c|c|c|c|c|c|c|}
\hline \multirow[b]{2}{*}{ Study or Subgroup } & \multicolumn{3}{|c|}{ Cases(CAH) } & \multicolumn{3}{|c|}{ Controls(No $\mathrm{CAH}$ ) } \\
\hline & Mean & SD & Total & Mean & SD & To \\
\hline Falhammar 2007 over 30 years & 1.132 & 0.0747 & 33 & 1.184 & 0.0816 & \\
\hline Falhammar 2007 under $30 y e a r s$ & 1.128 & 0.0784 & 24 & 1.186 & 0.0765 & \\
\hline Falhammar 2013 & 1.17 & 0.11 & 30 & 1.27 & 0.1 & \\
\hline Guo 1996 & 1.14 & 0.11 & 11 & 1.176 & 0.19 & \\
\hline Haagenfeldt 2000 & 1.12 & 0.0721 & 13 & 1.13 & 0.0693 & \\
\hline King 2006 & 1.05 & 0.12 & 26 & 1.2 & 0.14 & \\
\hline Sciannamblo 2006 Females & 1.125 & 0.0891 & 15 & 1.154 & 0.0825 & \\
\hline Sciannamblo 2006 Males & 1.159 & 0.093 & 15 & 1.278 & 0.0955 & \\
\hline Stikkelbroeck 2003 Females & 1.11 & 0.06 & 15 & 1.14 & 0.07 & \\
\hline Stikkelbroeck 2003 Males & 1.16 & 0.11 & 15 & 1.21 & 0.07 & \\
\hline Total $(95 \% \mathrm{Cl})$ & & & 197 & & & \\
\hline $\begin{array}{l}\text { Heterogeneity: } \mathrm{Chi}^{2}=16.45, \mathrm{df} \\
\text { Test for overall effect: } \mathrm{Z}=6.69\end{array}$ & $\begin{array}{l}9(P=0 \\
<0.000\end{array}$ & $\begin{array}{l}0.06) ; 1^{2}= \\
001)\end{array}$ & $45 \%$ & & & \\
\hline
\end{tabular}

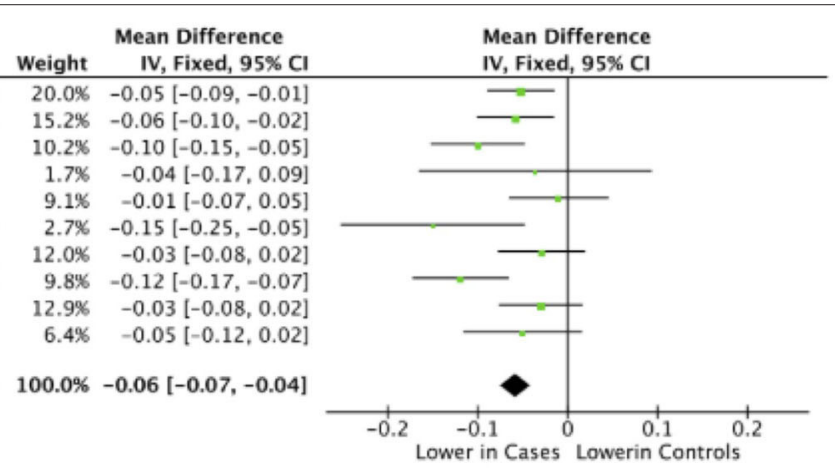

FIGURE 2 | Meta-analysis of total body bone mineral density $\left(\mathrm{g} / \mathrm{cm}^{2}\right)$ in patients with congenital adrenal hyperplasia compared to matched controls. 


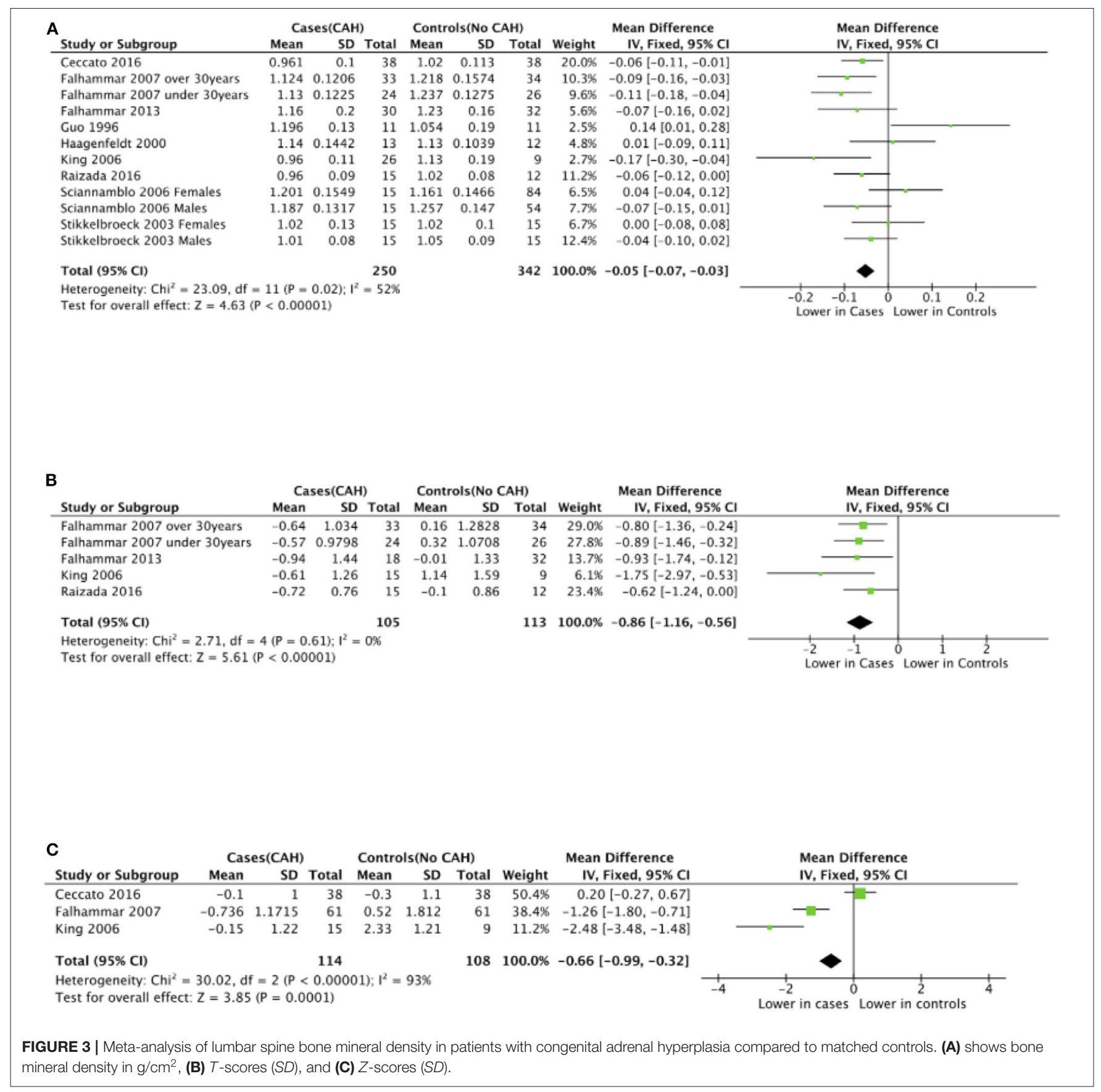

was then converted to a quality measure based on AHRQ standards (48). The reviewers then assigned high, moderate or low risk of bias to studies of good, fair, and poor quality, respectively.

\section{Glucocorticoid Type and Mean Dose}

The type of glucocorticoid used, average daily glucocorticoid dose and the results of included studies are shown in Table 3. Studies used between two to four different types of glucocorticoids with a proportion of patients in each study on more than one type of glucocorticoid for variable duration. Prednisolone was the most commonly used glucocorticoid. The average daily dose of glucocorticoid varied between 9.66 and $22 \mathrm{mg} / \mathrm{m}^{2} /$ day hydrocortisone equivalents dose. For studies that reported individual patient glucocorticoid doses (23) or average daily dose without adjusting for body surface area (33), the average daily dose adjusted for body surface area was calculated using mean population adult body surface area for United Kingdom (50) and Sweden (51). 


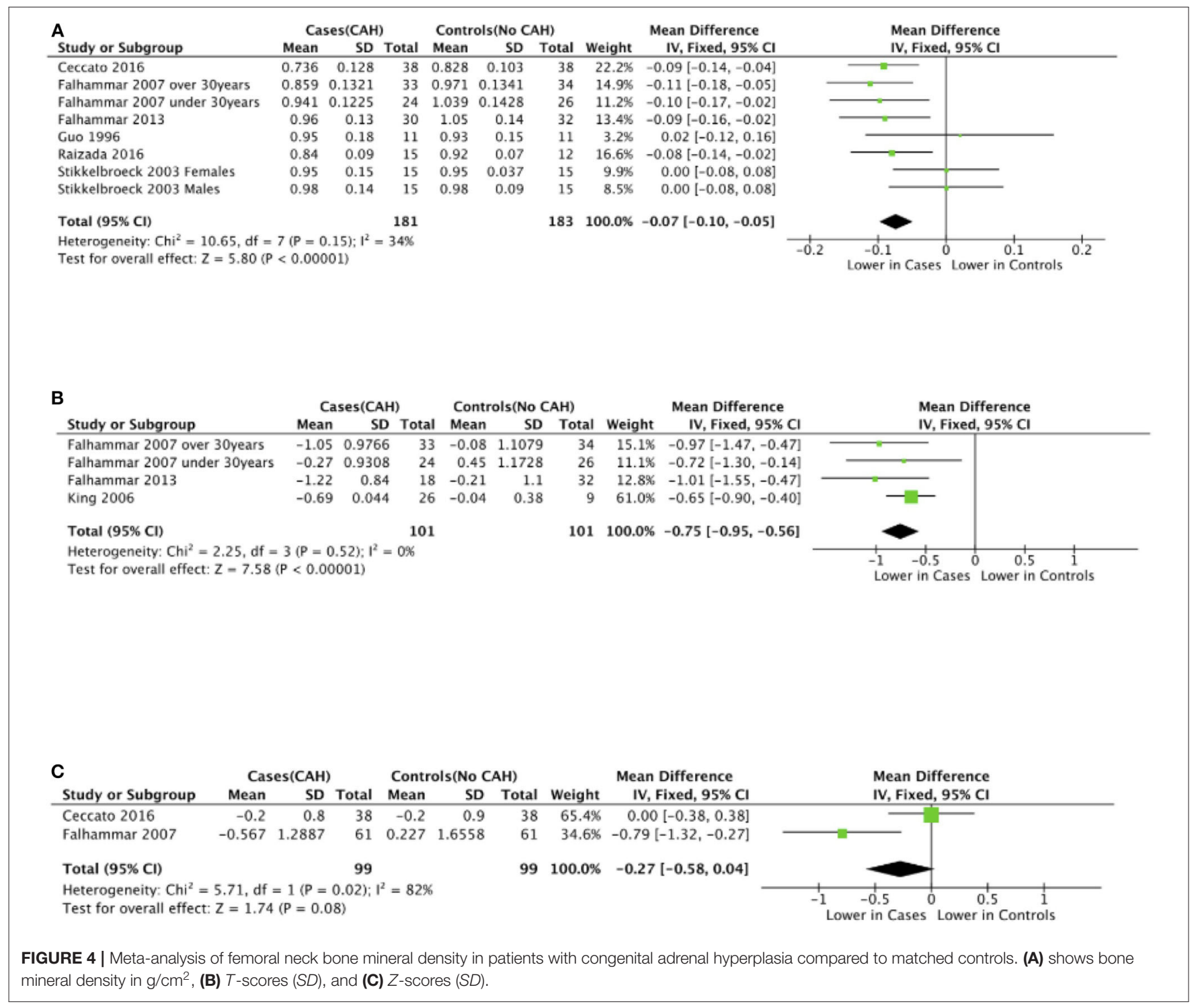

\section{Meta-Analyses of BMD}

Seven studies reported total body BMD (Figure 2) (23, 25, 3337), nine studies reported lumbar spine BMD (Figure 3) (23, 25, 33-37, 42, 43), six studies reported femoral neck bone mineral density, (Figure 4) $(23,25,36,37,42,43)$ one study reported total femur BMD (42) and one study reported forearm BMD (43) Meta-analyses were performed for data variables where more than one study reported values for cases and controls. As some studies provided mean values for subgroups (males/females, $<30$ years/ $>30$ years) without an overall mean value, these subgroups were included as separate studies in the meta-analyses to minimize bias. Meta-analysis of the studies showed decreased BMD $\left(\mathrm{g} / \mathrm{cm}^{2}\right)$ at all commonly measured sites in $\mathrm{CAH}$ compared to controls with a mean difference for total body BMD of $-0.06 \mathrm{~g} / \mathrm{cm}^{2}(95 \% \mathrm{CI}-0.07,-0.04)$, lumbar spine BMD of $-0.05 \mathrm{~g} / \mathrm{cm}^{2}(95 \% \mathrm{CI}-0.07,-0.03)$, and femoral neck BMD of $-0.07 \mathrm{~g} / \mathrm{cm}^{2}$ (95\%CI $\left.-0.10,-0.05\right)$. The $T$-scores and $Z$-scores (SD) at lumbar spine and femoral neck were also lower in cases compared to controls with a mean difference for lumbar spine $T$-score of -0.86 (95\%CI -1.16 , -0.56), lumbar spine $Z$-score of -0.66 (95\% CI -0.99, -0.32), femoral neck $T$-score of -0.75 (95\% CI $-0.95,-0.56)$, femoral neck $Z$-score of -0.27 (95\% CI -0.58, 0.04) (Figures 2-4, Table 5).

\section{Meta-Analysis of Bone Turnover Markers}

There was variable reporting and results of bone turnover markers in the included studies as shown in Table 4. CTX was reported in four studies $(34,36,37,42)$, BALP was reported in four studies $(23,36,37,42)$, osteocalcin and NTX were reported in two studies $(23,37)$. Meta-analyses of bone turnover markers showed that osteocalcin and NTX were lower in cases compared 
TABLE 3 | Glucocorticoid type and hydrocortisone equivalent dose of patients with congenital adrenal hyperplasia in the included studies.

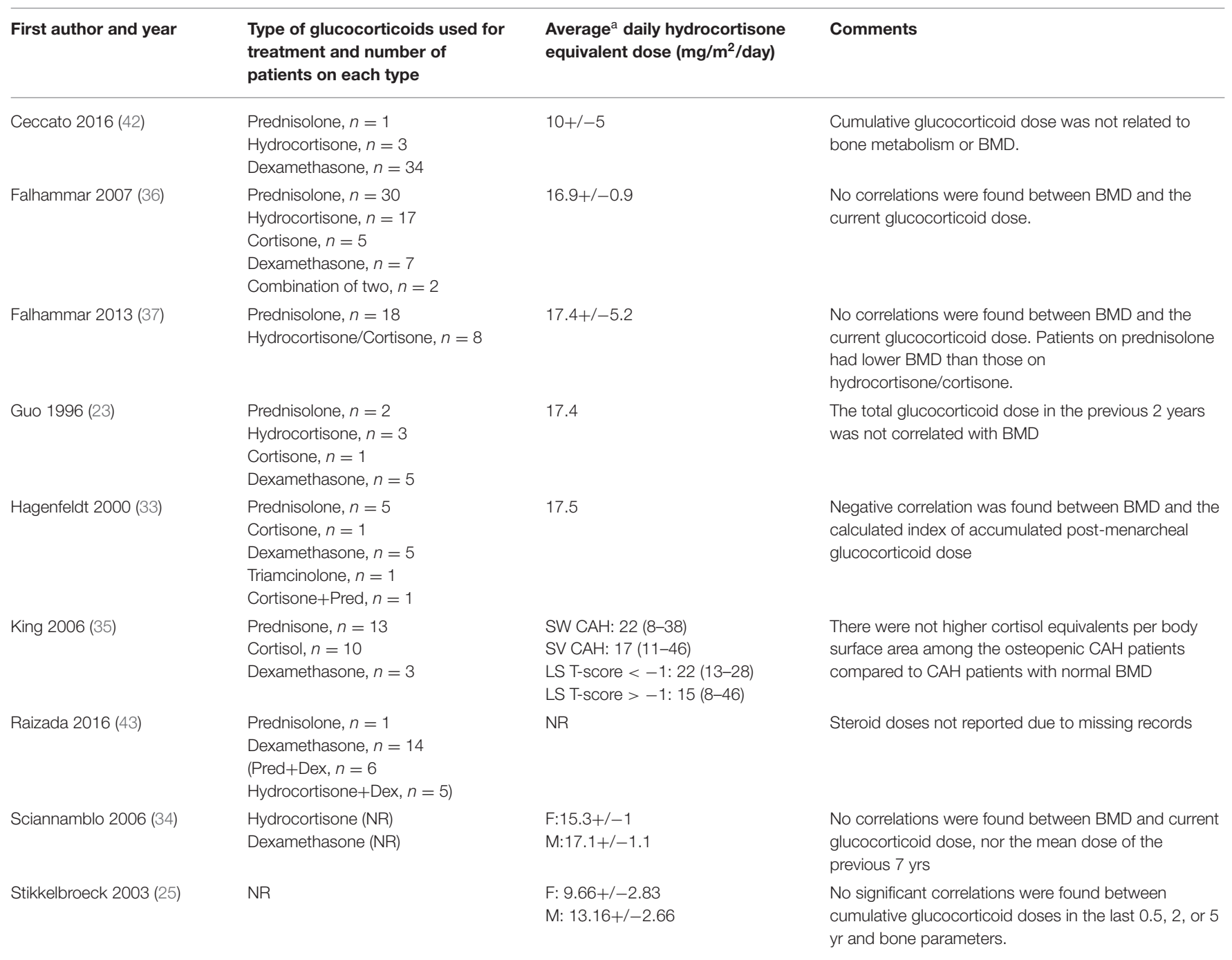

$N R$, not reported; $B M D$, bone mineral density.

a average presented as mean+/- standard deviation or mean+/- standard error of mean or median(range).

to controls whilst there was no significant difference in CTX and BALP between cases and controls (Figure 5). None of the studies reported P1NP or pyridinoline cross-links.

\section{Publication Bias}

According to the Cochrane Handbook of Systematic Reviews for Interventions (version 6.0) "tests for funnel plot asymmetry should be used only when there are at least 10 studies included in the metaanalysis, because when there are fewer studies the power of the tests is low" and "none of the recommended tests for funnel plot asymmetry is implemented in RevMan." As we used RevMan to perform all our meta-analyses and our systematic review includes nine studies, we are unable to comment on the possibility of publication bias.

\section{Sensitivity Analyses}

The results of the meta-analyses remained unchanged when the analyses were limited to subgroups of female patients (Supplemental Figures 1-3).

\section{Grading of Evidence}

The overall evidence was of low quality given the observational design of the included studies (Table 5). The evidence was downgraded for reduction in total body $T$ - and $Z$-score, lumbar spine $T$ - and $Z$-score as well as femoral neck $T$ - and $Z$-score to very low quality due to imprecision of the effect size estimates resulting from wide confidence intervals. The evidence was not downgraded for reduction in total body BMD and lumbar spine BMD despite $I^{2}>40$ due to clinical homogeneity of the included studies and the narrow 
TABLE 4 | Bone turnover markers in included studies of patients with congenital adrenal hyperplasia.

\begin{tabular}{|c|c|c|c|c|c|c|c|c|}
\hline $\begin{array}{l}\text { First author } \\
\text { and year of } \\
\text { publication }\end{array}$ & \multicolumn{2}{|l|}{ CTX (ng/L) } & \multicolumn{2}{|c|}{ BALP (units/L) ${ }^{a}$} & \multicolumn{2}{|c|}{ Osteocalcin (mcg/L) } & \multicolumn{2}{|c|}{ Urinary NTX/creatinine (nmol/mmol) } \\
\hline $\begin{array}{l}\text { Ceccato } \\
2016(42)\end{array}$ & $380.2+/-166.6$ & $331.7+/-208$ & $11.1+/-5.4$ & $11.2+/-3.8$ & NR & NR & NR & NR \\
\hline $\begin{array}{l}\text { Falhammar } \\
2013(37)\end{array}$ & $445+/-148$ & $455+/-247$ & $10.3+/-3.5$ & $12.7+/-6.9$ & $18.6+/-7$ & $25.6+/-8.5$ & $53+/-21$ & $51+/-34$ \\
\hline $\begin{array}{l}\text { Guo } 1996 \\
(23)\end{array}$ & NR & NR & $32(19-58)$ & $45(25-75)$ & $4(1-7)$ & $5.6(2.8-9)$ & $32(10-58)$ & $58(30-110)$ \\
\hline $\begin{array}{l}\text { Raizada } \\
2016 \text { (43) }\end{array}$ & NR & NR & 120 & NR & NR & NR & NR & NR \\
\hline
\end{tabular}

NR, not reported.

a Units varied between studies: microg/I(Ceccato 2016), microkat/L(Falhammar 2007,2013), U/L(Guo 1996), IU/L Raizada 2016).

confidence intervals around the effect size estimates. The evidence was not downgraded for risk of bias, indirectness, inconsistency, or publication bias. None of the studies met criteria for upgradation of quality of evidence for any of the outcomes.

\section{DISCUSSION}

This is the first systematic review and meta-analysis analyzing BMD in adult patients with CAH. The metaanalysis found consistently lower BMD at all commonly measured sites in individuals with $\mathrm{CAH}$ compared to age-and sex-matched controls.

The lower BMD in patients with $\mathrm{CAH}$ has been attributed to glucocorticoid overtreatment and the resulting catabolic effects of systemic glucocorticoids on bone in some studies $(32,33)$. The normal physiological cortisol production rate is estimated to be $9-11 \mathrm{mg} / \mathrm{m}^{2}$ (52), while the average glucocorticoid dose in the included studies was $9.66-22 \mathrm{mg} / \mathrm{m}^{2}$ hydrocortisone equivalents dose. Thus, most patients with $\mathrm{CAH}$ seemed to be on supraphysiological doses of glucocorticoids and this may be the main cause for low BMD. Hagenfeldt et al. found that the calculated index of accumulated post menarcheal glucocorticoid was the strongest determinant for all bone variables except BMD of spine and was calculated by multiplying the daily glucocorticoid dose expressed as cortisol equivalents with actual age minus age at menarche and dividing the result with the body surface area at the time of the study (33). King et al. suggested an association with oversuppression of adrenal steroidogenesis and decreased BMD in CAH patients (35). Similarly, Falhammar et al. found in both females and males with $\mathrm{CAH}$ subnormal levels of testosterone and DHEAS suggesting overtreatment with glucocorticoids which might have been a reason for low BMD $(36,37)$. However, most of the studies in our systematic review did not show any relationship between BMD and glucocorticoid dose. We could not perform a dose response analysis as some studies only had the current dose of glucocorticoids $(36,37)$ and those calculating a glucocorticoid dose over several years estimated the total dose from certain timepoint $(23,25,33,34,42)$, (i.e., no study had the life-time dose exposure of glucocorticoids). Hence, we cannot draw any conclusions regarding dose response relationship.

Areal BMD as measured using DXA can be largely affected by size of bone leading to overestimation in larger bones and underestimation in smaller bones (53). CAH patients were 5$12 \mathrm{~cm}$ shorter than controls in studies included in our review. It has been shown that patients with $\mathrm{CAH}$ fail to achieve optimal adult height due to several factors (54). Excess adrenal androgens can result in accelerated linear growth and premature fusion of the epiphyses, ultimately compromising adult stature. Furthermore, treatment of $\mathrm{CAH}$ with glucocorticoids, even at replacement doses, especially around time of puberty has been associated with poor growth with resultant short stature in these patients (54). In our systematic review, two studies $(36,42)$ reported BMD corrected for height, two studies reported BMD corrected for $\operatorname{BMI}(35,43)$ and the rest reported uncorrected $\mathrm{BMD}$. In those correcting for height, Ceccato et al. found that only femoral neck BMD was lower in $\mathrm{CAH}$ patients compared to controls (42) while Falhammar et al. found that BMD remained lower in all studied sites in $\mathrm{CAH}$ patients compared to controls (36). King et al. and Raizada et al. found no association between BMD and $\operatorname{BMI}(35,43)$. Given that only two of the included studies reported BMD corrected for height, it is not possible to draw any conclusions regarding the 


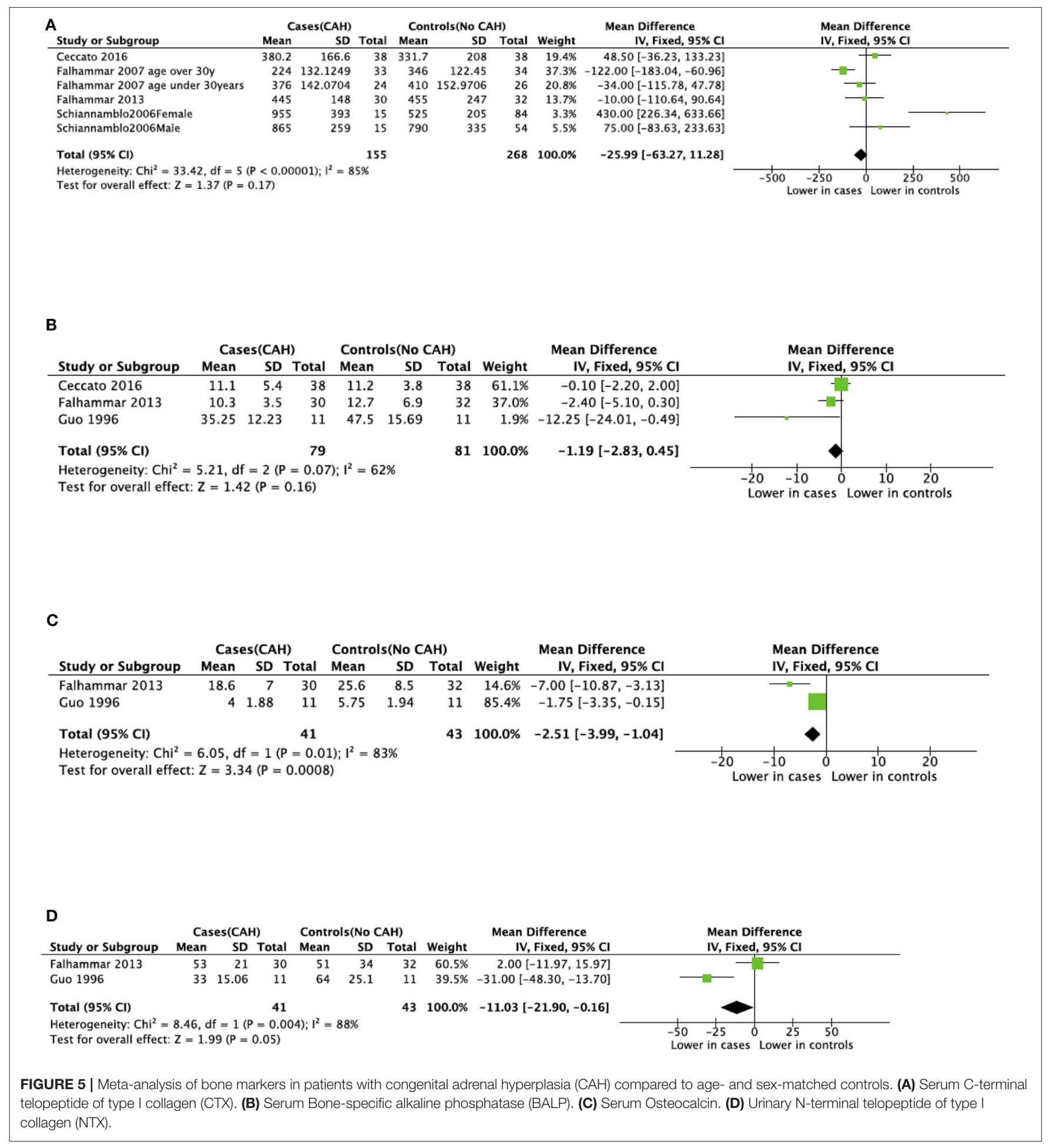

impact of height on differences in BMD observed between cases and controls.

Only one study reported BMD at forearm and there was no difference between cases and controls (43) However a recent study by El-Maouche et al. showed patients with classic CAH had lower BMD than patients with nonclassic $\mathrm{CAH}$, with the greatest difference at the forearm and DHEAS was the only independent significant predictor of BMD at the forearm, whole body and spine (19). We need further studies measuring cortical bone density to 
TABLE 5 | Summary of findings of included studies.

\begin{tabular}{|c|c|c|c|c|c|c|}
\hline $\begin{array}{l}\text { Outcome } \\
\text { measures }\end{array}$ & \multicolumn{2}{|c|}{ Results: absolute effects } & $\begin{array}{l}\text { Results: relative } \\
\text { effects mean } \\
\text { difference }(95 \% \mathrm{Cl})\end{array}$ & $\begin{array}{l}\text { Number of } \\
\text { participants (studies) }\end{array}$ & $\begin{array}{l}\text { Quality of } \\
\text { evidence } \\
\text { (GRADE) }\end{array}$ & Comments \\
\hline Total Body BMD & $\begin{array}{l}\text { Mean total body } \\
\text { BMD ranged from } \\
1.05 \text { to } 1.17\end{array}$ & $\begin{array}{l}\text { Mean total body } \\
\text { BMD ranged from } \\
1.13 \text { to } 1.278\end{array}$ & $-0.06(-0.07,-0.04)$ & $489(7)$ & Low & \\
\hline $\begin{array}{l}\text { Total Body } \\
\text { Z-score }\end{array}$ & $\begin{array}{l}\text { Mean total body } \\
Z \text {-score was } \\
0.0772\end{array}$ & $\begin{array}{l}\text { Mean total body } \\
Z \text {-score was } 0.933\end{array}$ & $-0.86(-1.25,-0.46)$ & $50(1)$ & Very low ${ }^{2}$ & $\begin{array}{l}\text { Only one study reported Total } \\
\text { Body Z-scores in }<30 \text { years } \\
\text { subgroup }\end{array}$ \\
\hline $\begin{array}{l}\text { Lumbar Spine } \\
\text { T-score }\end{array}$ & $\begin{array}{l}\text { Mean Lumbar } \\
\text { Spine T-score } \\
\text { ranged from } \\
-0.94 \text { to }-0.57\end{array}$ & $\begin{array}{l}\text { Mean Lumbar } \\
\text { Spine T-score } \\
\text { ranged from }-0.1 \\
\text { to } 1.14\end{array}$ & $-0.86(-1.16,-0.56)$ & $218(4)$ & Very low ${ }^{3}$ & \\
\hline $\begin{array}{l}\text { Lumbar Spine } \\
\text { Z-score }\end{array}$ & $\begin{array}{l}\text { Mean Lumbar } \\
\text { Spine } Z \text {-score } \\
\text { ranged from } \\
-0.736 \text { to }-0.1\end{array}$ & $\begin{array}{l}\text { Mean Lumbar } \\
\text { Spine } Z \text {-score } \\
\text { ranged from }-0.5 \\
\text { to } 2.33\end{array}$ & $-0.66(-0.99,-0.32)$ & $222(3)$ & Very low ${ }^{4}$ & \\
\hline $\begin{array}{l}\text { Femoral Neck } \\
\text { BMD }\end{array}$ & $\begin{array}{l}\text { Mean Femoral } \\
\text { Neck BMD ranged } \\
\text { from } 0.726 \text { to } 0.98\end{array}$ & $\begin{array}{l}\text { Mean Femoral } \\
\text { Neck BMD ranged } \\
\text { from } 0.8 \text { to } 1.05\end{array}$ & $-0.07(-0.10,-0.05)$ & $364(6)$ & Low & \\
\hline $\begin{array}{l}\text { Femoral Neck } \\
\text { T-score }\end{array}$ & $\begin{array}{l}\text { Mean Femoral } \\
\text { Neck T-score } \\
\text { ranged from } \\
-1.22 \text { to }-0.27\end{array}$ & $\begin{array}{l}\text { Mean Femoral } \\
\text { Neck T-score } \\
\text { ranged from } \\
-0.27 \text { to } 0.45\end{array}$ & $-0.75(-0.95,-0.56)$ & $202(3)$ & Very low ${ }^{5}$ & \\
\hline
\end{tabular}

Population, Adults(>18 years) with Congenital Adrenal Hyperplasia (CAH); Exposure, Therapeutic glucocorticoid use; Control, Age and Sex-matched adults without Congenital Adrenal Hyperplasia; Outcome, Risk of Osteopenia and/or Osteoporosis; BMD, Bone Mineral Density; Cl, Confidence Intervals; GRADE, Grading of Recommendations Assessment Development and Evaluation. Foothotes about differences in subgroups age and gender based for each variable to be done 1,2,3,4,5,6: Level of Evidence downgraded from Low to Very Low for imprecision of effect size estimates secondary to small sample sizes and wide confidence intervals.

understand the etiology of these differences on cortical bone in $\mathrm{CAH}$ patients.

Sexual steroids increase osteoblast activity, decrease the formation, and activity of osteoclasts, stimulate longitudinal growth of long bones during puberty (55). The excessive estrogen action in pediatric $\mathrm{CAH}$ patients from peripheral conversion of androgens causes advanced maturation of the epiphyseal plate, resulting in increased bone age and acquisition of peak bone mass compared with healthy children (56). DHEAS correlates with bone turnover before peak bone mass (57), which may represent a direct effect on bone metabolism or the role of DHEAS as a substrate for conversion to other sex steroids. One of the aims of glucocorticoid therapy in CAH is to suppress the hyperandrogenism, however, often the androgen levels are lower than in controls $(11,37)$. Low levels of androgen as a result of glucocorticoid effect and failure of typical adrenarche in classical
CAH patients have been shown to cause bone loss due to an imbalance between bone resorption and bone formation (58). Thus, androgens are important in both maintenance of bone mass and peak bone mass accrual.

Bone turnover markers were reported in 6 of the included studies with varied results. Osteocalcin and NTX were lower in cases than controls whereas CTX and BALP were not significantly different between cases and controls $(23,34,36,37,42,43)$. These conflicting findings could be due to variable age of study populations, assay differences, and different glucocorticoid preparations and doses.

No association was found between genotypes of $\mathrm{CAH}$ and BMD in three studies $(33,36,37)$. The risk of fractures in $\mathrm{CAH}$ patients was reported by three of the included studies $(36,37,43)$. No fractures were reported in any of the CAH cases by Raizada 
et al. (43). On the other hand, more fractures were found in $\mathrm{CAH}$ women than control (36), while no difference in fracture frequency could be demonstrated in males with CAH (37). However, fragility fractures usually occur in older age and very few patients with $\mathrm{CAH}$ above the age of 50 years were included in the studies in this review. Low BMD is strongly associated with the risk of fractures but it is well-recognized that different risk factors, such as age, history of a prior fragility fracture, steroid use and many others are independent contributors to the risk of fractures (59). Moreover, fractures can also occur due to sports activities, especially hazardous, which were more common in females but not in males with $\mathrm{CAH}(60,61)$. One study reported that the fractures had often occurred during sport activities, however, the underlying trauma was not recorded systematically (37). There are also other studies reporting on fractures in $\mathrm{CAH}$ but then there was no control group making it difficult to assess the risk $(19,39,44,62)$. Thus, future studies examining fractures, how they occurred (fragility vs. traumatic fractures) in patients with $\mathrm{CAH}$ compared to controls are required.

Our systematic review and meta-analysis had several limitations. The relatively small total sample size of 598 makes it difficult to draw firm conclusions about the outcomes. As all included studies were retrospective observational studies, the possibility of results having been influenced by unknown confounders cannot be ruled out. Individual patient data was not assessed and numerical data from one study (23) was deduced from graphs possibly introducing measurement bias. However, the latter is unlikely to have influenced the direction and magnitude of results given the small sample size $(n=22)$ of the study. Despite the fact that only studies with $\mathrm{CAH}$ patients 16 years and older and controls were included, the study cohorts were still quite clinically heterogenous due to different genotypes of $\mathrm{CAH}$, inclusion of both sexes, inclusion of different age groups and different DXA scans used to measure BMD. These factors could also have resulted in moderate degree of statistical heterogeneity as evidenced from the $I^{2}$ statistic. Not all variables related to bone health were reported in each study and all the factors related to BMD could not be assessed. However, in all studies the controls were measured on the same DXA scan as their cases and all results point in the same direction reassuring that the conclusions are valid. Finally, inability to perform a glucocorticoid dose-response analysis and the low to very low quality of evidence for the reported outcomes in the included studies limits the strength of our conclusions.

\section{Future Directions}

Bone health is an important issue. Well-designed, longterm prospective studies that assess all relevant measures of bone health in homogenous populations (age, sex, race, genotype) in relation to treatment are needed. Randomized studies are not possible instead structured long-term follow up are warranted, assessing glucocorticoid dose over time, and bone age during childhood years. Better endpoints than BMD would be fractures or markers of bone quality/strength but very few studies in $\mathrm{CAH}$ have investigated those, hence more studies are needed. The growth pattern (i.e., accelerated growth indicating insufficient dose and androgen excess or the opposite would also give important information). BMD in relation to glucocorticoid dose and hormonal control during puberty could give important insights to improve treatment strategies since puberty is thought to be the time in life for maximum bone mineral accrual. The timing of achieving peak bone mass in patients with $\mathrm{CAH}$ is lacking and timing of puberty is on average often earlier in this patient group. More data on peak bone mass in relation to puberty would be valuable. Bone markers would also be of importance to follow over time.

\section{CONCLUSION}

BMD seemed to be consistently low in CAH patients compared to controls. Although we could not analyse the dose-response relationship between glucocorticoid dose and BMD, it would be prudent to avoid overtreatment. The current Endocrine Society Guidelines recommends BMD screening in any patient with $\mathrm{CAH}$ with a prolonged period of higher-than-average glucocorticoid dosing, or in patients who have had a non-traumatic fracture (2). The current systematic review and meta-analysis may support a more liberal BMD screening and monitoring in patients with $\mathrm{CAH}$.

\section{DATA AVAILABILITY STATEMENT}

All datasets presented in this study are included in the article/Supplementary Material.

\section{AUTHOR CONTRIBUTIONS}

SR, VG, and HF: project conception and protocol preparation. SR and VG: idenfication of articles, data extraction, and data analysis. SR, VG, AN, and HF: manuscript preparation and review. All authors contributed to the article and approved the submitted version.

\section{FUNDING}

This project was supported by grants from the Magnus Bergvall Foundation (Grant numbers 2017-02138, 2018-02566, and 2019-03149).

\section{SUPPLEMENTARY MATERIAL}

The Supplementary Material for this article can be found online at: https://www.frontiersin.org/articles/10.3389/fendo. 2020.00493/full\#supplementary-material 


\section{REFERENCES}

1. Falhammar H, Thoren M. Clinical outcomes in the management of congenital adrenal hyperplasia. Endocrine. (2012) 41:35573. doi: 10.1007/s12020-011-9591-x

2. Speiser PW, Arlt W, Auchus RJ, Baskin LS, Conway GS, Merke DP, et al. Congenital adrenal hyperplasia due to steroid 21-hydroxylase deficiency: an endocrine society clinical practice guideline. J Clin Endocrinol Metab. (2018) 103:4043-88. doi: 10.1210/jc.2018-01865

3. Arlt W, Willis DS, Wild SH, Krone N, Doherty EJ, Hahner S, et al. Health status of adults with congenital adrenal hyperplasia: a cohort study of 203 patients. J Clin Endocrinol Metab. (2010) 95:5110-21. doi: 10.1210/jc.2010-0917

4. El-Maouche D, Arlt W, Merke DP. Congenital adrenal hyperplasia. Lancet. (2017) 390:2194-210. doi: 10.1016/S0140-6736(17)31431-9

5. Gidlof S, Falhammar H, Thilen A, von Dobeln U, Ritzen M, Wedell A, et al. One hundred years of congenital adrenal hyperplasia in Sweden: a retrospective, population-based cohort study. Lancet Diabetes Endocrinol. (2013) 1:35-42. doi: 10.1016/S2213-8587(13)70007-X

6. Al Alawi AM, Nordenstrom A, Falhammar H. Clinical perspectives in congenital adrenal hyperplasia due to 3beta-hydroxysteroid dehydrogenase type 2 deficiency. Endocrine. (2019) 63:40721. doi: 10.1007/s12020-018-01835-3

7. Bulsari K, Falhammar H. Clinical perspectives in congenital adrenal hyperplasia due to 11beta-hydroxylase deficiency. Endocrine. (2017) 55:1936. doi: 10.1007/s12020-016-1189-x

8. Dean B, Chrisp GL, Quartararo M, Maguire AM, Hameed S, King BR, et al. P450 oxidoreductase deficiency: a systematic review and meta-analysis of genotypes, phenotypes and their relationships. J Clin Endocrinol Metab. (2019) 105:dgz255. doi: 10.1210/clinem/dgz255

9. Nordenstrom A, Falhammar H. Management of endocrine disease: diagnosis and management of the patient with non-classic CAH due to 21-hydroxylase deficiency. Eur J Endocrinol. (2018) 180:R127-45. doi: 10.1530/EJE-18-0712

10. Hannah-Shmouni F, Morissette R, Sinaii N, Elman M, Prezant TR, Chen $\mathrm{W}$, et al. Revisiting the prevalence of nonclassic congenital adrenal hyperplasia in US Ashkenazi jews and caucasians. Genet Med. (2017) 19:12769. doi: 10.1038 /gim.2017.46

11. Falhammar H, Filipsson H, Holmdahl G, Janson PO, Nordenskjold A, Hagenfeldt K, et al. Metabolic profile and body composition in adult women with congenital adrenal hyperplasia due to 21-hydroxylase deficiency. J Clin Endocrinol Metab. (2007) 92:110-16. doi: 10.1210/jc.2006-1350

12. Falhammar H, Frisen L, Hirschberg AL, Norrby C, Almqvist C, Nordenskjold A, et al. Increased cardiovascular and metabolic morbidity in patients with 21-hydroxylase deficiency: a Swedish population-based national cohort study. J Clin Endocrinol Metab. (2015) 100:3520-8. doi: 10.1210/JC.2015-2093

13. Van Staa TP, Leufkens HG, Abenhaim L, Zhang B, Cooper C. Use of oral corticosteroids and risk of fractures. J Bone Miner Res. (2000) 15:9931000. doi: 10.1359/jbmr.2000.15.6.993

14. van Staa TP, Leufkens HG, Cooper C. The epidemiology of corticosteroidinduced osteoporosis: a meta-analysis. Osteoporos Int. (2002) 13:77787. doi: 10.1007/s001980200108

15. Chappard D, Legrand E, Basle MF, Fromont P, Racineux JL, Rebel $\mathrm{A}$, et al. Altered trabecular architecture induced by corticosteroids: a bone histomorphometric study. J Bone Miner Res. (1996) 11:67685. doi: 10.1002/jbmr.5650110516

16. Dalle Carbonare L, Arlot ME, Chavassieux PM, Roux JP, Portero NR, Meunier PJ. Comparison of trabecular bone microarchitecture and remodeling in glucocorticoid-induced and postmenopausal osteoporosis. J Bone Miner Res. (2001) 16:97-103. doi: 10.1359/jbmr.2001.16.1.97

17. Weinstein RS, Jilka RL, Parfitt AM, Manolagas SC. Inhibition of osteoblastogenesis and promotion of apoptosis of osteoblasts and osteocytes by glucocorticoids. Potential mechanisms of their deleterious effects on bone. J Clin Invest. (1998) 102:274-82. doi: 10.1172/JCI2799

18. Kasperk CH, Wakley GK, Hierl T, Ziegler R. Gonadal and adrenal androgens are potent regulators of human bone cell metabolism in vitro. J Bone Miner Res. (1997) 12:464-71. doi: 10.1359/jbmr.1997.12.3.464

19. El-Maouche D, Collier S, Prasad M, Reynolds JC, Merke DP. Cortical bone mineral density in patients with congenital adrenal hyperplasia due to 21-hydroxylase deficiency. Clin Endocrinol. (2015) 82:330-7. doi: 10.1111/cen.12507

20. Sellers EP, MacGillivray MH. Blunted adrenarche in patients with classical congenital adrenal hyperplasia due to 21-hydroxylase deficiency. Endocr Res. (1995) 21:537-44. doi: 10.1080/07435809509030471

21. Girgis R, Winter JS. The effects of glucocorticoid replacement therapy on growth, bone mineral density, and bone turnover markers in children with congenital adrenal hyperplasia. J Clin Endocrinol Metab. (1997) 82:39269. doi: $10.1210 /$ jcem.82.12.4320

22. Fleischman A, Ringelheim J, Feldman HA, Gordon CM. Bone mineral status in children with congenital adrenal hyperplasia. J Pediatr Endocrinol Metab. (2007) 20:227-35. doi: 10.1515/JPEM.2007.20.2.227

23. Guo CY, Weetman AP, Eastell R. Bone turnover and bone mineral density in patients with congenital adrenal hyperplasia. Clin Endocrinol. (1996) 45:53541. doi: 10.1046/j.1365-2265.1996.00851.x

24. Mora S, Saggion F, Russo G, Weber G, Bellini A, Prinster C, et al. Bone density in young patients with congenital adrenal hyperplasia. Bone. (1996) 18:337-40. doi: 10.1016/8756-3282(96)00003-8

25. Stikkelbroeck NM, Oyen WJ, van der Wilt GJ, Hermus AR, Otten BJ. Normal bone mineral density and lean body mass, but increased fat mass, in young adult patients with congenital adrenal hyperplasia. J Clin Endocrinol Metab. (2003) 88:1036-42. doi: 10.1210/jc.2002-021074

26. Christiansen P, Molgaard C, Muller J. Normal bone mineral content in young adults with congenital adrenal hyperplasia due to 21-hydroxylase deficiency. Horm Res. (2004) 61:133-6. doi: 10.1159/000075588

27. Gussinye M, Carrascosa A, Potau N, Enrubia M, Vicens-Calvet E, Ibanez $\mathrm{L}$, et al. Bone mineral density in prepubertal and in adolescent and young adult patients with the salt-wasting form of congenital adrenal hyperplasia. Pediatrics. (1997) 100:671-4. doi: 10.1542/peds.100.4.671

28. Zimmermann A, Sido PG, Schulze E, Al Khzouz C, Lazea C, Coldea $\mathrm{C}$, et al. Bone mineral density and bone turnover in romanian children and young adults with classical 21-hydroxylase deficiency are influenced by glucocorticoid replacement therapy. Clin Endocrinol. (2009) 71:47784. doi: 10.1111/j.1365-2265.2008.03518.x

29. Cameron FJ, Kaymakci B, Byrt EA, Ebeling PR, Warne GL, Wark JD. Bone mineral density and body composition in congenital adrenal hyperplasia. J Clin Endocrinol Metab. (1995) 80:2238-43. doi: 10.1210/jcem.80.7.76 08286

30. de Almeida Freire PO, de Lemos-Marini SH, Maciel-Guerra AT, Morcillo AM, Matias Baptista MT, de Mello MP, et al. Classical congenital adrenal hyperplasia due to 21-hydroxylase deficiency: a cross-sectional study of factors involved in bone mineral density. J Bone Miner Metab. (2003). 21:396401. doi: 10.1007/s00774-003-0434-6

31. Paganini C, Radetti G, Livieri C, Braga V, Migliavacca D, Adami S. Height, bone mineral density and bone markers in congenital adrenal hyperplasia. Horm Res. (2000) 54:164-8. doi: 10.1159/000053253

32. Jaaskelainen J, Voutilainen R. Bone mineral density in relation to glucocorticoid substitution therapy in adult patients with 21-hydroxylase deficiency. Clin Endocrinol. (1996) 45:70713. doi: 10.1046/j.1365-2265.1996.8620871.x

33. Hagenfeldt K, Martin Ritzen E, Ringertz H, Helleday J, Carlstrom K. Bone mass and body composition of adult women with congenital virilizing 21hydroxylase deficiency after glucocorticoid treatment since infancy. Eur J Endocrinol. (2000) 143:667-71. doi: 10.1530/eje.0.1430667

34. Sciannamblo M, Russo G, Cuccato D, Chiumello G, Mora S. Reduced bone mineral density and increased bone metabolism rate in young adult patients with 21-hydroxylase deficiency. J Clin Endocrinol Metab. (2006) 91:44538. doi: 10.1210/jc.2005-2823

35. King JA, Wisniewski AB, Bankowski BJ, Carson KA, Zacur HA, Migeon CJ. Long-term corticosteroid replacement and bone mineral density in adult women with classical congenital adrenal hyperplasia. J Clin Endocrinol Metab. (2006) 91:865-9. doi: 10.1210/jc.2005-0745

36. Falhammar H, Filipsson H, Holmdahl G, Janson PO, Nordenskjold A, Hagenfeldt K, et al. Fractures and bone mineral density in adult women with 21-hydroxylase deficiency. J Clin Endocrinol Metab. (2007) 92:46439. doi: 10.1210/jc.2007-0744

37. Falhammar H, Filipsson Nystrom H, Wedell A, Brismar K, Thoren M. Bone mineral density, bone markers, and fractures in adult males 
with congenital adrenal hyperplasia. Eur J Endocrinol. (2013) 168:33141. doi: 10.1530/EJE-12-0865

38. Bachelot A, Plu-Bureau G, Thibaud E, Laborde K, Pinto G, Samara D, et al. Long-term outcome of patients with congenital adrenal hyperplasia due to 21hydroxylase deficiency. Horm Res. (2007) 67:268-76. doi: 10.1159/000098017

39. Koetz KR, Ventz M, Diederich S, Quinkler M. Bone mineral density is not significantly reduced in adult patients on low-dose glucocorticoid replacement therapy. J Clin Endocrinol Metab. (2012) 97:85-92. doi: 10.1210/jc.2011-2036

40. Nermoen I, Bronstad I, Fougner KJ, Svartberg J, Oksnes M, Husebye ES, et al. Genetic, anthropometric and metabolic features of adult Norwegian patients with 21-hydroxylase deficiency. Eur J Endocrinol. (2012) 167:50716. doi: 10.1530/EJE-12-0196

41. Finkielstain GP, Kim MS, Sinaii N, Nishitani M, Van Ryzin C, Hill SC, et al. Clinical characteristics of a cohort of 244 patients with congenital adrenal hyperplasia. J Clin Endocrinol Metab. (2012) 97:442938. doi: 10.1210/jc.2012-2102

42. Ceccato F, Barbot M, Albiger N, Zilio M, De Toni P, Luisetto G, et al. Longterm glucocorticoid effect on bone mineral density in patients with congenital adrenal hyperplasia due to 21-hydroxylase deficiency. Eur J Endocrinol. (2016) 175:101-6. doi: 10.1530/EJE-16-0104

43. Raizada N, Jyotsna VP, Upadhyay AD, Gupta N. Bone mineral density in young adult women with congenital adrenal hyperplasia. Indian J Endocrinol Metab. (2016) 20:62-6. doi: 10.4103/2230-8210.172283

44. Riehl G, Reisch N, Roehle R, Claahsen van der Grinten H, Falhammar $\mathrm{H}$, Quinkler M. Bone mineral density and fractures in congenital adrenal hyperplasia: findings from the dsd-LIFE study. Clin Endocrinol. (2019) 92:284-94. doi: 10.1111/cen.14149

45. Arisaka O, Hoshi M, Kanazawa S, Numata M, Nakajima D, Kanno S, et al. Preliminary report: effect of adrenal androgen and estrogen on bone maturation and bone mineral density. Metabolism. (2001) 50:377379. doi: 10.1053/meta.2001.21678

46. Moher D, Liberati A, Tetzlaff J, Altman DG. Preferred reporting items for systematic reviews and meta-analyses: the PRISMA statement. PLoS Med. (2009) 6:e1000097. doi: 10.1371/journal.pmed.1000097

47. Wells GA SB, O'Connell D, Peterson J, Welch V, Losos M, Tugwell P. The Newcastle-ottawa scale (nos) for assessing the quality of nonrandomised studies in meta-analyses. (2019). Available online at: http://www.ohri.ca/ Programs/clinical_epidemiology/default.asp

48. Borge TC, Aase H, Brantsaeter AL, Biele G. The importance of maternal diet quality during pregnancy on cognitive and behavioural outcomes in children: a systematic review and meta-analysis. BMJ Open. (2017) 7:e016777. doi: 10.1136/bmjopen-2017-016777

49. Schünemann H, Brożek J, Guyatt G, Oxman A. GRADE Handbook for Grading Quality of Evidence and Strength of Recommendations. Updated October (2013). The GRADE Working Group (2013). Available online at: guidelinedevelopment.org/handbook

50. Sacco JJ, Botten J, Macbeth F, Bagust A, Clark P. The average body surface area of adult cancer patients in the UK: a multicentre retrospective study. PLoS ONE. (2010) 5:e8933. doi: 10.1371/journal.pone.0008933

51. Andersen K, Rasmussen F, Neovius M, Tynelius P, Sundstrom J. Body size and risk of atrial fibrillation: a cohort study of 1.1 million young men. J Intern Med. (2018) 283:346-55. doi: 10.1111/joim.12717
52. Kraan GP, Dullaart RP, Pratt JJ, Wolthers BG, Drayer NM, De Bruin R. The daily cortisol production reinvestigated in healthy men. The serum and urinary cortisol production rates are not significantly different. J Clin Endocrinol Metab. (1998) 83:1247-52. doi: 10.1210/jcem.83. 4.4694

53. Liu XS, Cohen A, Shane E, Yin PT, Stein EM, Rogers H, et al. Bone density, geometry, microstructure, and stiffness: relationships between peripheral and central skeletal sites assessed by DXA, HR-pQCT, and cQCT in premenopausal women. J Bone Miner Res. (2010) 25:222938. doi: $10.1002 / \mathrm{jbmr} .111$

54. Lin-Su K, Harbison MD, Lekarev O, Vogiatzi MG, New MI. Final adult height in children with congenital adrenal hyperplasia treated with growth hormone. J Clin Endocrinol Metab. (2011) 96:1710-7. doi: 10.1210/jc.20102699

55. Bonfig W, Bechtold S, Schmidt H, Knorr D, Schwarz HP. Reduced final height outcome in congenital adrenal hyperplasia under prednisone treatment: deceleration of growth velocity during puberty. J Clin Endocrinol Metab. (2007) 92:1635-9. doi: 10.1210/jc.2006-2109

56. White PC, Speiser PW. Congenital adrenal hyperplasia due to 21-hydroxylase deficiency. Endocr Rev. (2000) 21:245-91. doi: 10.1210/er.21.3.245

57. Walsh JS, Henry YM, Fatayerji D, Eastell R. Hormonal determinants of bone turnover before and after attainment of peak bone mass. Clin Endocrinol. (2010) 72:320-7. doi: 10.1111/j.1365-2265.2009.03606.x

58. Lindberg MK, Vandenput L, Moverare Skrtic S, Vanderschueren D, Boonen S, Bouillon R, et al. Androgens and the skeleton. Minerva Endocrinol. (2005) 30:15-25.

59. Cosman F, de Beur SJ, LeBoff MS, Lewiecki EM, Tanner B, Randall S, et al. Clinician's guide to prevention and treatment of osteoporosis. Osteoporos Int. (2014) 25:2359-81. doi: 10.1007/s00198-014-2794-2

60. Frisen L, Nordenstrom A, Falhammar H, Filipsson H, Holmdahl G, Janson $\mathrm{PO}$, et al. Gender role behavior, sexuality, and psychosocial adaptation in women with congenital adrenal hyperplasia due to CYP21A2 deficiency. J Clin Endocrinol Metab. (2009) 94:3432-9. doi: 10.1210/jc.2009-0636

61. Falhammar H, Nystrom HF, Thoren M. Quality of life, social situation, and sexual satisfaction, in adult males with congenital adrenal hyperplasia. Endocrine. (2014) 47:299-307. doi: 10.1007/s12020-0130161-2

62. Falhammar H, Claahsen-van der Grinten H, Reisch N, Slowikowska-Hilczer J, Nordenstrom A, Roehle R, et al. Health status in 1040 adults with disorders of sex development (DSD): a European multicenter study. Endocr Connect. (2018) 7:466-78. doi: 10.1530/EC-18-0031

Conflict of Interest: The authors declare that the research was conducted in the absence of any commercial or financial relationships that could be construed as a potential conflict of interest.

Copyright (c) 2020 Rangaswamaiah, Gangathimmaiah, Nordenstrom and Falhammar. This is an open-access article distributed under the terms of the Creative Commons Attribution License (CC BY). The use, distribution or reproduction in other forums is permitted, provided the original author(s) and the copyright owner(s) are credited and that the original publication in this journal is cited, in accordance with accepted academic practice. No use, distribution or reproduction is permitted which does not comply with these terms. 